This article was downloaded by: [Memorial University of Newfoundland]

On: 15 March 2015, At: 14:43

Publisher: Routledge

Informa Ltd Registered in England and Wales Registered Number: 1072954

Registered office: Mortimer House, 37-41 Mortimer Street, London W1T

3J H, UK

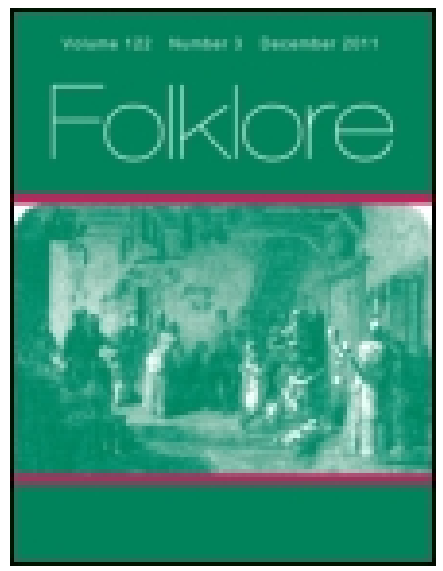

\title{
Folklore
}

Publication details, including instructions for authors and subscription information:

http:// www. tandfonline.com/loi/ rfol20

\section{Witchcraft in Scotland}

Alex Keiller

Published online: 14 Feb 2012.

To cite this article: Alex Keiller (1922) Witchcraft in Scotland, Folklore, 33:3, 303-303, DOI: 10.1080/0015587X. 1922.9720557

To link to this article: http:// dx. doi.org/ 10.1080/ 0015587X.1922.9720557

\section{PLEASE SCROLL DOWN FOR ARTICLE}

Taylor \& Francis makes every effort to ensure the accuracy of all the information (the "Content") contained in the publications on our platform. However, Taylor \& Francis, our agents, and our licensors make no representations or warranties whatsoever as to the accuracy, completeness, or suitability for any purpose of the Content. Any opinions and views expressed in this publication are the opinions and views of the authors, and are not the views of or endorsed by Taylor \& Francis. The accuracy of the Content should not be relied upon and should be independently verified with primary sources of information. Taylor and Francis shall not be liable for any losses, actions, claims, proceedings, demands, costs, expenses, damages, and other liabilities whatsoever or howsoever caused arising directly or indirectly in connection with, in relation to or arising out of the use of the Content.

This article may be used for research, teaching, and private study purposes. Any substantial or systematic reproduction, redistribution, reselling, loan, sub-licensing, systematic supply, or distribution in any form to anyone is 
expressly forbidden. Terms $\&$ Conditions of access and use can be found at http://www.tandfonline.com/page/terms-and-conditions 
In the paper referred to there is an error. The war compelled me to write from memory, which deceived me. On p. 63 the "Valerian gens" should be read for "Valentian." The reference is to De-Marchi, Il Culto Privato di Roma Antica, pt. ii. pp. 29-39, where the sacred legends of the Valerii are discussed. Valentia and Valeria appear, however, to be both derived from an old form, Valesia, a Sabine stock : $i b .$, p. 31 .

Finally, the Valentinus who founded the Valentinians was clearly not one of the "three or more" saints of that name canonised by the Church of Rome. That there is much uncertainty as to the identity of the saint connected with the customs of St. Valentine's Day is clear from the fact that all these three or more have their festival on the I4th of February. ${ }^{1}$ Valentinus the Gnostic never seems to have been canonised in any regular sense, but that would hardly have prevented a rite associated with his teaching from being transferred to the day of a St. Valentine by the folk.

H. A. Rose.

\section{Witchcraft in Scotrand.}

WhEs reading that most remarkable work furgen by James Branch Cabell, published by the Bodley Head, in I92I, I was interested to observe that the scene of the author's only reference to witchcraft was laid at Morven. Any student of Witchcraft in Aberdeenshire will recollect that the hot-bed of the cult inland was in such places as Blelac, Logie-Coldstone, and Tarland. Blelac lies on the slope of Morven Hill, Coldstone and Tarland lie just to the east of it. One cannot help speculating as to whether the choice of the name was purely arbitrary and accidental, or whether this minor point was an example of the erudition of the author even more startling than those contained in the trenchant allegories round which his story is formed.

4 Charles Street,

Alex. Keiller.

London, W. I.

1 The Catholic Encyclopadia, xv. p. 254. 